\author{
Iwona Jażewicz \\ https://orcid.org/0000-0002-5698-442X \\ Akademia Pomorska w Słupsku \\ Instytut Geografii Społeczno-Ekonomicznej i Turystyki \\ iwona.jazewicz@apsl.edu.pl \\ Aleksandra Zienkiewicz \\ https:/ / orcid.org/0000-0003-2323-913X \\ Akademia Pomorska w Słupsku \\ Instytut Geografii Społeczno-Ekonomicznej i Turystyki \\ aleksandra.zienkiewicz@apsl.edu.pl
}

\title{
DETERMINANTY ROZWOJU OSADNICTWA LETNISKOWEGO NA PRZYKŁADZIE GMINY STĘŻYCA
}

\begin{abstract}
Abstrakt: W opracowaniu przedstawiono wyniki badań dotyczących przestrzeni wypoczynku indywidualnego na działkach letniskowych. Jest to próba identyfikacji uwarunkowań rozwoju osadnictwa letniskowego na przykładzie gminy Stężyca położonej w centralnej części Pojezierza Kaszubskiego. W artykule wskazano uwarunkowania związane z miejscem lokalizacji działek letniskowych oraz z motywacjami i oczekiwaniami ich właścicieli. W rezultacie przeprowadzonych badań stwierdzono, że rozwój osadnictwa letniskowego w gminie Stężyca determinują przede wszystkim walory przyrodnicze i krajobrazowe oraz dobra dostępność czasowa i przestrzenna, nie mniej ważny pozostaje również motyw więzi rodzinnych i sentyment do miejsca urodzenia.
\end{abstract}

Słowa kluczowe: osadnictwo letniskowe, działki letniskowe, gmina Stężyca, Pojezierze Kaszubskie.

\section{WSTĘP}

W badaniach turystycznych ważne miejsce zajmuje obecnie problem wypoczynku podmiejskiego. Wokół każdego miasta istnieje specjalna strefa wypoczynkowa dla mieszkańców, którzy na krótko opuszczają miasto. Punkty koncentracji ruchu turystycznego $\mathrm{w}$ tej strefie stają się zaś niekiedy zaczątkiem kolejnych większych osiedli, a czasami miast. Bardzo często wsie letniskowe, do których wyjeżdżają mieszkańcy miast, są miejscowościami położonymi $\mathrm{w}$ pobliżu nadmorskich miast, ośrodków sportów zimowych czy ośrodków związanych z wodami śródlądowymi (Beaujeu-Garnier, Chabot, 1971).

Kompleksowe badania nad funkcją wypoczynkową na obszarach stref podmiejskich prowadzone były przede wszystkim w odniesieniu do dużych miast (Dziegieć, Liszewski, 1984). Szczególne miejsce miała praca Liszewskiego (1987), przedstawiająca genezę i rozwój osadnictwa turystycznego na obszarze podmiejskim Łodzi. Szczegółowe badania empiryczne nad zasięgiem, formami i poziomem rozwoju funkcji wypoczynkowej w strefie podmiejskiej Łodzi prowadził Matczak (1985). Studia obejmowały również propozycje mierników badania tej funkcji, tj.: analizę struktur użytkowania ziemi (Liszewski, 1985; Matczak, 1991), wielkość ruchu wypoczynkowego (Matczak, 1987a), morfologię osiedli podmiejskich (Makowska-Iskierka, 2004; Matczak, 1984), a także analizę budownictwa letniskowego (Matczak, 1986). Natomiast badania Włodarczyka (1999), Szkupa (2003) i Makowskiej-Iskierki (2011) identyfikowały przestrzeń wypoczynkową na wybranych obszarach strefy podmiejskiej Łodzi. Ważne miejsce w zakresie aspektów rozwoju funkcji wypoczynkowej zajmują opracowania dotyczące strefy podmiejskiej Warszawy, w których opisano badania uwarunkowań lokalizacji drugich domów (Kowalczyk, 1990) oraz prace prezentujące wpływ czynników przyrodniczych i społecznych na jakość wypoczynku w drugich domach (Kowalczyk, 1993). Z kolei pogłębione badania terenów wypoczynkowych w strefie podmiejskiej Krakowa prowadził Faracik (2006, 2011). Natomiast Grucza i Grucza (2007) zaprezentowały czynniki lokalizacji drugich domów w strefie oddziaływania 
aglomeracji gdańskiej. Analizę porównawczą wybranych aspektów rozwoju funkcji wypoczynkowej w strefie podmiejskiej Warszawy, Łodzi i Krakowa przedstawiła zaś Jakóbczyk-Gryszkiewicz (1995).

Podobne badania nad funkcją wypoczynkową prowadzono w odniesieniu do: miast i osiedli podmiejskich (m.in. Liszewski, 1991; Matczak, 1987b), dolin rzek (Wiluś, 1997; Wojciechowska, 1998), jednostek administracyjnych (Adamiak, 2012; Jażewicz, Zienkiewicz, 2017; Matulewski, Tomczak, 2013) czy regionów przyrodniczych (Dziegieć, 1989; Krukowska, Świeca, 2008). Mniej liczne były prace dotyczące wypoczynku indywidualnego w skali kraju (Adamiak, Sokołowski, 2012; Drugie domy..., 2011; Durydiwka, 2012; Heffner, 2015; Kowalczyk, 1986, 1994; Wyrzykowski, 1986).

W niniejszym opracowaniu podjęto próbę identyfikacji determinant rozwoju osadnictwa letniskowego na przykładzie kaszubskiej gminy Stężyca, położonej administracyjnie na terenie powiatu kartuskiego, w sąsiedztwie aglomeracji gdańskiej. Z jednej strony wskazano uwarunkowania związane z miejscem lokalizacji działek letniskowych, ze szczególnym uwzględnieniem ich walorów przyrodniczych, krajobrazowych i kulturowych, bliskości stałego miejsca zamieszkania oraz poziomu dostępności komunikacyjnej. Z drugiej strony zaprezentowano motywacje i oczekiwania właścicieli tych działek.

Materiał źródłowy wykorzystany w opracowaniu opierał się na informacjach wtórnych zawartych w spisach i rejestrach udostępnionych przez Urząd Gminy w Stężycy, Wydział Geodezji oraz Wydział Budownictwa Starostwa Powiatowego w Kartuzach, a także Powiatowy Inspektorat Nadzoru Budowlanego w Kartuzach. Szczególnie ważne i niezbędne okazały się jednak materiały pierwotne pochodzące $\mathrm{z}$ badań ankietowych $(104 \text { ankiety })^{1} \mathrm{i}$ inwentaryzacji terenowej. Podstawowe badania terenowe zostały przeprowadzone $\mathrm{w}$ miesiącach letnich (od lipca do sierpnia 2013 r.) wśród właścicieli działek letniskowych. Do badań wybrano dwa obręby geodezyjne - Niesiołowice i Sikorzyno - które charakteryzowały się największą liczbą działek letniskowych i pozwoleń wydanych na budowę domów letniskowych. Podmiotem opracowania jest gmina Stężyca. Zgodnie z regionalizacją fizycznogeograficzną Augustowskiego (1979) jest ona położona na terenie Pojezierza Kaszubskiego, pod względem administracyjnym zaś należy do powiatu kartuskiego w województwie pomorskim. Elementem indywidualizującym gminę jest jej usytuowanie w granicach tzw. Kaszub etnicznych (Mordawski, 2008), co wyraża się w dialekcie kaszubskim, jak również $\mathrm{w}$ sztuce ludowej oraz obiektach kultury materialnej. W 2014 r. gmina zajmowała 160,5 km² powierzchni i zamieszkiwało ją około 10 tys. osób. W skład gminy wchodzi 14 obrębów geodezyjnych (Borucino, Czaple, Gapowo, Gołubie, Łączyno, Łosienice, Niesiołowice, Pierszczewo, Potuły, Sikorzyno, Stężyca, Szymbark, Zgorzałe i Żuromino), które stały się podstawowymi jednost- kami przestrzennymi w prowadzonych badaniach. Taki wybór był podyktowany dostępnością materiału statystycznego pochodzącego z Urzędu Gminy w Stężycy oraz Starostwa Powiatowego w Kartuzach. Bardzo ważnym elementem pracy było określenie zakresu czasowego. Poruszone w opracowaniu kwestie zostały zaprezentowane w ujęciu dynamicznym, bowiem rozważania dotyczą lat 1989-2011.

\section{ZASOBY NATURALNE I ANTROPOGENICZNE GMINY STĘŻYCA}

Dzisiejszy krajobraz naturalny gminy Stężyca został ukształtowany głównie przez procesy rzeźbotwórcze związane z ostatnim zlodowaceniem północnopolskim, a tylko częściowo w wyniku procesów, które miały miejsce po ustąpieniu lądolodu. Efektami działalności glacjalnej na tym obszarze są np. znaczne deniwelacje terenu, wynoszące maksymalnie aż $168,5 \mathrm{~m}$ (od lustra wody Jeziora Ostrzyckiego - 160,1 m n.p.m. do szczytowych partii wzniesienia Wieżycy - 328,6 m n.p.m.). Tak znaczne różnice wysokości względnej sprawiają, że obszar gminy jest niezwykle atrakcyjny szczególnie dla osób uprawiających sporty zimowe. Przez najwyższe partie pasma morenowego ciągnie się czarny szlak turystyczny Wzgórz Szymbarskich. Na wzgórzach znajdują się stoki narciarskie i wyciągi, np. trasy narciarskie na terenie Centrum Wypoczynkowego „Koszałkowo”, zlokalizowane na terenach prywatnych pomiędzy Szymbarkiem a Wieżycą. Trasy te są bardzo dobrze przygotowane do zjazdów zimowych. Najdłuższa z nich ma $300 \mathrm{~m}$ długości, a różnica poziomów pomiędzy poszczególnymi szlakami wynosi do $50 \mathrm{~m}$. Obiekt wyposażony jest $w$ trzy wyciągi orczykowe. Na zboczach dodatkowo zostały wytyczone trzy zjazdy do snowtubingu o długości 70, 100 i $120 \mathrm{~m}$. W Centrum funkcjonuje także wypożyczalnia sprzętu zimowego oraz szkółka narciarska. Inną atrakcją gminy jest trzytarasowa Kaszubska Wieża Widokowa im. Jana Pawła II o wysokości $35 \mathrm{~m}$. Z wieży rozpościera się widok na Wzgórza Szymbarskie, „Kółko Raduńskie" i szlak turystyczny - tzw. Drogę Kaszubską.

Szczególnie istotnym walorem przyrodniczym badanego obszaru są wody powierzchniowe. Centralna oraz południowa część gminy należy do dorzecza rzeki Raduni, część południowo-wschodnia do dorzecza Wieżycy, część północno-zachodnia do dorzecza Słupi, a południowo-zachodnia do dorzecza Wdy. Niezwykle atrakcyjne turystycznie pozostają także jeziora w gminie Stężyca - wskaźnik jeziorności wynosi tam ok. 15\%. Większość jezior należy do typu rynnowego, np. Jezioro Stężyckie, Raduńskie Górne i Dolne, Lubawisko, Dąbrowskie, Ostrzyckie, Patulskie, Bukrzyno Duże i Małe oraz Zamkowisko Duże i Małe. Najdłuższym (poza Ra- 
Tabela 1. Morfometria jezior położonych na terenie gminy Stężyca

\begin{tabular}{|c|c|c|c|c|c|c|c|c|}
\hline \multirow[b]{2}{*}{ Lp. } & \multirow[b]{2}{*}{ Nazwa jeziora } & \multirow{2}{*}{$\begin{array}{l}\text { Wysokość } \\
\text { położenia } \\
\text { (m n.p.m.) }\end{array}$} & \multirow[b]{2}{*}{$\begin{array}{l}\text { Powierzchnia } \\
\text { (ha) }\end{array}$} & \multicolumn{2}{|c|}{ Maksymalna } & \multicolumn{2}{|c|}{ Linia brzegowa } & \multirow{2}{*}{$\begin{array}{c}\text { Głębokość } \\
\text { maks. } \\
(\mathrm{m})\end{array}$} \\
\hline & & & & $\begin{array}{l}\text { długość } \\
\text { (m) }\end{array}$ & $\begin{array}{l}\text { szerokość } \\
(\mathrm{m})\end{array}$ & $\begin{array}{c}\text { długość } \\
(\mathrm{m})\end{array}$ & rozwój & \\
\hline 1 & Stężyckie & 162,7 & 61,5 & 2250 & 460 & 5400 & 1,95 & 11,7 \\
\hline 2 & Raduńskie Górne & 162,0 & 386,5 & 5900 & 901 & 15500 & 1,18 & 43,0 \\
\hline 3 & Ostrzyckie & 159,0 & 266,3 & 7000 & 800 & 18000 & 3,15 & 19,4 \\
\hline 4 & Bukrzyno Małe & 161,0 & 17,8 & 850 & 300 & 2000 & 1,34 & 4,1 \\
\hline 5 & Bukrzyno Duże & 161,0 & 20,8 & 875 & 300 & 2230 & 1,38 & 10,8 \\
\hline 6 & Patulskie & 159,5 & 97,6 & 3225 & 475 & 7235 & 2,06 & 7,76 \\
\hline 7 & Dąbrowskie & 166,2 & 67,3 & 2442 & 450 & 5502 & 1,89 & 20,7 \\
\hline 8 & Lubowisko & 166,5 & 33,9 & 1860 & 360 & 4000 & 2,01 & 7,6 \\
\hline 9 & Zamkowisko Małe & 177,4 & 2,7 & 280 & 145 & 800 & 1,37 & 7,4 \\
\hline 10 & Zamkowisko Duże & 177,4 & 6,9 & 470 & 155 & 1236 & 1,32 & 17,8 \\
\hline 11 & Kamionko & 178,0 & 16,5 & 620 & 440 & 2100 & 1,49 & 12,8 \\
\hline
\end{tabular}

Źródło: Sobolewski, Borowiak, Borowiak, Skowron (2014); Szukalski (1965); opracowanie własne.

duńskim Dolnym), a zarazem najgłębszym jeziorem w gminie jest Jezioro Raduńskie Górne o powierzchni 387,2 ha i maksymalnej głębokości 43 m (tab. 1).

Poza walorami krajobrazowymi oraz niezwykłym nagromadzeniem jezior na szczególne zainteresowanie turystów zasługują również lasy, które zajmują 30,1\% prezentowanego obszaru. Są to m.in. lasy łęgowe, bukowe, dębowo-bukowe, olsy, bory (szczególnie sosnowe), brzeziny bagienne.

Bogactwo fauny i flory oraz piękno krajobrazu zostały zaakcentowane poprzez utworzenie 15 czerwca 1983 r. Kaszubskiego Parku Krajobrazowego. W gminie Stężyca znajdują się także dwa rezerwaty przyrody. Pierwszy z nich, "Ostrzycki Las”, został utworzony w 1960 r. na obszarze 55,13 ha na zachodnim brzegu Jeziora Ostrzyckiego. Drugi, „Szczyt Wieżyca”, o powierzchni 33,59 ha, został utworzony w 1962 r. na szczytowej części wzniesień morenowych na Pomorzu. Pozostałe obszary i obiekty chronione to pomniki przyrody ożywionej i nieożywionej - Gowidliński Obszar Chronionego Krajobrazu (o powierzchni 325 ha), zespoły przyrodniczo-krajobrazowe: „Dolina Łeby” w Kaszubskim Parku Krajobrazowym, „Rynna Raduńska”, ,Rynna Dąbrowsko-Ostrzycka”.

Ogół walorów przyrodniczych terenu, na którym znajduje się opisywana gmina, sprawia, że obfituje on w dogodne warunki do uprawiania szeroko rozumianej turystyki kwalifikowanej (turystyki pieszej; wodnej - kajakowej, motorowodnej, żeglarskiej i podwodnej; narciarskiej, kolarskiej, motorowej) z wykorzystaniem istniejących szlaków turystycznych, m.in.:

- szlak wodny, tzw. Kółko Raduńskie, o długości ok. 40 km; trasa spływu przebiega przez jeziora: Radunskie Górne, Raduńskie Dolne, Kłodno, Białe, Małe Brodno, Wielkie Brodno, Ostrzyckie, Patulskie, Dąbrowskie, Lubawisko;

- szlak pieszy, tzw. czarny, o długości ok. 23 km; przebiegający przez: Wieżycę, Szymbark, Potuły, jezioro Kniewo, Gołubie, Leśnictwo Uniradzkie,
Zgorzałe, Jezioro Raduńskie, Łączno, Wygodę Łączyńską;

- szlak pieszy o nazwie Szlak Kaszubski, tzw. czerwony, o długości ok. $12 \mathrm{~km}$, przebiegający według trasy: wieś Krzeszna - Jezioro Patulskie - wieś Pierszczewo - jezioro Zamkowisko - wieś Gołubie - Jezioro Dąbrowskie;

- pieszy Szlak Kamiennych Kręgów, tzw. szlak zielony, o długości ok. 5 km, przebiegający od Jeziora Długiego do wsi Niesiołowice.

Poza zasobami naturalnymi na uwagę zasługują również liczne atrakcje antropogeniczne. Jednym z najbardziej znanych i najczęściej odwiedzanych miejsc w gminie jest Centrum Edukacji i Promocji Regionu w Szymbarku. Jego chlubą są: zbiór różnego rodzaju narzędzi ciesielskich, kołodziejskich, rolniczych, medycznych oraz gospodarstwa domowego, wykorzystywanych od XVIII w. do czasu wybuchu II wojny światowej, Dom Sybiraka oraz sławny już w kraju dom do góry nogami i jedna z najdłuższych desek świata wykonana przez Kaszubów, o długości 36,93 m i wadze 1100 kg. Z kolei w rejonie leśnictwa Uniradze można zwiedzać cmentarzysko kurhanowe, które datuje się na okres od późnej epoki brązu do średniowiecza. W granicach gminy znajdują się też cztery obiekty wpisane do rejestru Wojewódzkiego Urzędu Ochrony Zabytków w Gdańsku, tj.: zespół dworsko-parkowy (dom rodowy Wybickich) w Sikorzynie, kościół pw. św. Katarzyny Aleksandryjskiej i kościół ewangelicki w Stężycy oraz zespół kościoła parafialnego pw. św. Józefa z plebanią w Wygodzie Łączyńskiej.

Ważnym obiektem turystycznym prezentowanej gminy pozostaje również Gołubieński Ogród Botaniczny, który został utworzony w 1971 r. Jest on zlokalizowany na skarpie wyższej terasy rynny pojeziernej Jeziora Patulskiego oraz nad jego brzegiem. Powierzchnia ogrodu wynosi 3,68 ha, z czego na obszarze 2,27 ha posadzono aż 5500 gatunków taksonów w warunkach ekosystemu zastępczego, 1,41 ha stanowi naturalna łąka 
z nagromadzonymi zbiorowiskami roślin naczyniowych (170 gatunków) i mszaków (ponad 20 gatunków). Rosną tu m.in. kalcyfity, które są reliktami borealnymi. Wśród rosnących tam roślin należy wymienić też gatunki chronione (191), wpisane do Polskiej Czerwonej Księgi Roślin (119 taksonów) i nowej czerwonej listy roślin (10 taksonów). Na mocy przepisów Konwencji Berneńskiej ochroną objęto także 14 gatunków dzikiej fauny i flory.

Do podwyższenia atrakcyjności turystycznej gminy Stężyca przyczyniają się liczne imprezy kulturalne organizowane głównie w sezonie letnim, którego inauguracja odbywa się corocznie w czerwcu. Podczas imprezy można oglądać paradę bryczek i wozów drabiniastych. Dużym zainteresowaniem wśród turystów cieszą się tradycyjnie obchodzone obrzędy nocy świętojańskiej, a poza tym „Majówka z gen. Józefem Wybickim”, , Turniej sołectw gminy Stężyca”, "Sobótki gminne” i "Dożynki gminne". Natomiast we wrześniu w Domu Sybiraka w Centrum Edukacji i Promocji Regionu w Szymbarku ma miejsce impreza patriotyczna pt. „Światowy dzień Sybiraka”, organizowana przez Polski Związek Sybiraków, w grudniu zaś odbywa się tam impreza „Inwazja Mikołajów” - zabawa, która jest skierowana przede wszystkim do dzieci.

Rozwój osadnictwa letniskowego na terenie gminy Stężyca determinowany jest wieloma cechami społeczno-demograficznymi osób odwiedzających ten obszar, jak również cechami fizycznogeograficznymi środowiska naturalnego oraz dostępnością komunikacyjną. Do społecznych uwarunkowań zalicza się przede wszystkim styl życia mieszkańców dużej aglomeracji trójmiejskiej, który przejawia się korzystaniem z uroków wsi podczas weekendów, świąt czy urlopów. Obszar gminy leży bowiem w 45,6\% na terenie Kaszubskiego Parku Krajobrazowego, który obejmuje ochroną urozmaiconą rzeźbę terenu poprzecinaną złożonym rozkładem jezior rynnowych, które w Rynnie Ostrzycko-Raduńskiej osiągają swój najbardziej reprezentatywny układ. Duże znaczenie $\mathrm{w}$ wyborze właśnie takiej destynacji mają także cisza i spokój panujące na terenach wiejskich, jak również inne cechy środowiska przyrodniczego, którymi raczej nie wyróżniają się duże miasta.

Osadnictwu letniskowemu sprzyja również rozwój środków transportu oraz budowa nowych dróg. Transport jest bowiem jednym z ważniejszych elementów wpływających na atrakcyjność danego obszaru i możliwości rozwoju turystyki. Podstawą sprawnego funkcjonowania transportu jest rozwinięta sieć dróg kolejowych i kołowych oraz jej dobry stan techniczny. Dodatkowo w korzystaniu z domów letniskowych duże znaczenie przypisuje się także możliwości szybkiego przemieszczenia się z miejsca zamieszkania do miejsca wypoczynku. Centrum gminy Stężyca położone jest w odległości mniej więcej $56 \mathrm{~km}$ od Gdańska, co przy wykorzystaniu istniejących dróg kołowych oznacza możliwość dotarcia na teren gminy w czasie ok. 1 godziny.
Rozwój osadnictwa letniskowego, jak również wszelkich obiektów infrastruktury turystycznej, zdeterminowany jest jednak w dużej mierze występowaniem na tym terenie licznych jezior - w gminie Stężyca wskaźnik jeziorności wynosi ok. 15\%. Największym z jezior, które w całości leżą na jej terenie jest Jezioro Raduńskie Górne o powierzchni 386,5 ha (tab. 1, rys. 1). Jeziora ze względu na swoje właściwości stanowią nie tylko atrakcję turystyczną, lecz także barierę osadniczą. W związku z tym w rozmieszczeniu domów letniskowych można zauważyć pewne prawidłowości przejawiające się w pasowym układzie ich lokalizacji wzdłuż jezior, głównie w centralnej i północnej części gminy.

Kolejnym ważnym czynnikiem występowania osadnictwa letniskowego na tym terenie jest obecność obszarów leśnych. Las bowiem jest niezbędnym zbiorem roślinności odgrywającym ważną rolę w procesie regeneracji sił psychicznych i fizycznych człowieka. Cechują go bowiem niezwykle korzystne właściwości, takie jak: czyste powietrze, cisza, naturalny krajobraz, brak terenów uprzemysłowionych lub zurbanizowanych oraz specyficzny mikroklimat. Obszary leśne dostarczają również przeżyć estetycznych, wpływają dodatnio na stan psychiczny organizmu i są szczególnie korzystne do realizowania celów turystycznych w porze późnego lata i jesieni (Zyber, 1977). Pod względem występowania lasów w omawianej gminie panują idealne warunki do rozwoju turystyki i osadnictwa letniskowego. Tereny zalesione w mniejszym odsetku znajdują się jedynie w północnej i północno-zachodniej części gminy, a lesistość wynosi tu ok. 30,1\%.

Na uwarunkowania rozwoju budownictwa letniskowego wpływają również w znacznym stopniu: charakter rzeźby terenu, warunki nawilgocenia gruntu i gleby, nachylenie czy ekspozycja zboczy i stoków oraz roślinność. Badania prowadzone nad zróżnicowaniem jednostek regionalnych na terenie Pojezierza Kaszubskiego wykazały, że omawiana gmina, w tym obszar Centralnych Wysoczyzn i Wzgórza Nadjeziorne, cechuje się największą dyferencjacją geoekologiczną (Gacki, Szukalski, 1979). Tym samym stanowi idealne miejsce do budowy drugich domów ze względu na fakt, że człowiek podświadomie w swych turystycznych i rekreacyjnych motywacjach poszukuje obszarów do wypoczynku, które wyróżniają się znaczną kontrastowością krajobrazu (Krzymowska-Kostrowicka, 1995).

\section{LICZBA, ROZMIESZCZENIE I WIELKOŚĆ DZIAŁEK LETNISKOWYCH GMINY STĘŻYCA}

W 2011 r. na terenie gminy Stężyca istniało 566 działek letniskowych położonych na terenie 14 obrębów geodezyjnych spośród 18 obrębów w gminie. Jak wspomniano wcześniej, największą liczbę działek letniskowych odno- 
towano $\mathrm{w}$ obrębach geodezyjnych Niesiołowice oraz Sikorzyno, w których zinwentaryzowano ponad połowę ogólnej liczby działek letniskowych (54,9\%). Obręb Niesiołowice należy do bardzo atrakcyjnych rejonów Pojezierza Kaszubskiego, jest bowiem położony w bezpośrednim sąsiedztwie jezior Długiego i Czarnego oraz na Szlaku Kamiennych Kręgów. Szczególnie atrakcyjny wypoczynek jest możliwy nad Jeziorem Czarnym, gdzie znajduje się zarybiane łowisko oraz stanica wodna „Nad Kamiennymi Kręgami". Omawiany obręb geodezyjny charakteryzuje się ponadto dość wysokim odsetkiem obszarów leśnych (39,6\% powierzchni obrębu), urozmaiconą rzeźbą terenu i młodoglacjalnymi formami jego ukształtowania. Drugim pod względem liczby działek letniskowych był obręb Sikorzyno, położony w południowej części gminy. Wieś Sikorzyno, jak również pozostałe miejscowości wiejskie $\mathrm{w}$ omawianym obrębie, mają urozmaicony krajobraz, ponadto znajdują się tam liczne jeziora i rozległe powierzchnie leśne (Zienkiewicz, 2016).

Rozpiętość ilościowa działek w poszczególnych obrębach była stosunkowo duża i wynosiła od 176 działek w obrębie geodezyjnym Niesiołowice do jednej działki na terenie obrębu geodezyjnego Zgorzałe (rys. 1, tab. 2).
Największa działka letniskowa zlokalizowana w gminie Stężyca miała powierzchnię $5550 \mathrm{~m}^{2}$, najmniejsza zaś - $281 \mathrm{~m}^{2}$, przy średniej dla całej gminy równej 1357,32 m² oraz medianie o wartości 983,36 m² (tab. 3). W odniesieniu do rozmieszczenia działek letniskowych można zauważyć ich podwyższoną koncentrację w centralnej i południowej części gminy. Lokalizacja działek wyraźnie ma związek z uwarunkowaniami środowiska przyrodniczego, a przede wszystkim z układem jezior rynnowych.

Jeziora w prezentowanej gminie tworzą specyficzny układ pasmowy, z podziałem na dwa pasma o kształcie dwóch łuków: wschodniego i zachodniego, które łączą się w miejscowości gminnej Stężyca. Na łuku zachodnim rozciągają się Jeziora Raduńskie, nad którymi położone są gminy: Łączyno, Borucino i Zgorzałe. Na łuku wschodnim znajduje się Jezioro Ostrzyckie, następnie łuk ten ciągnie się przez Jezioro Patulskie i miejscowość Gołubie, Jezioro Dąbrowskie oraz jezioro Lubowisko. Koncentracja działek letniskowych zauważalna jest głównie wzdłuż wymienionych jezior, dodatkowo rozległe powierzchnie leśne sprzyjają rozwojowi osadnictwa letniskowego. W części północno-zachodniej natomiast liczba działek letniskowych jest niewielka, gdyż ta część gminy pełni typowe funkcje rolnicze.

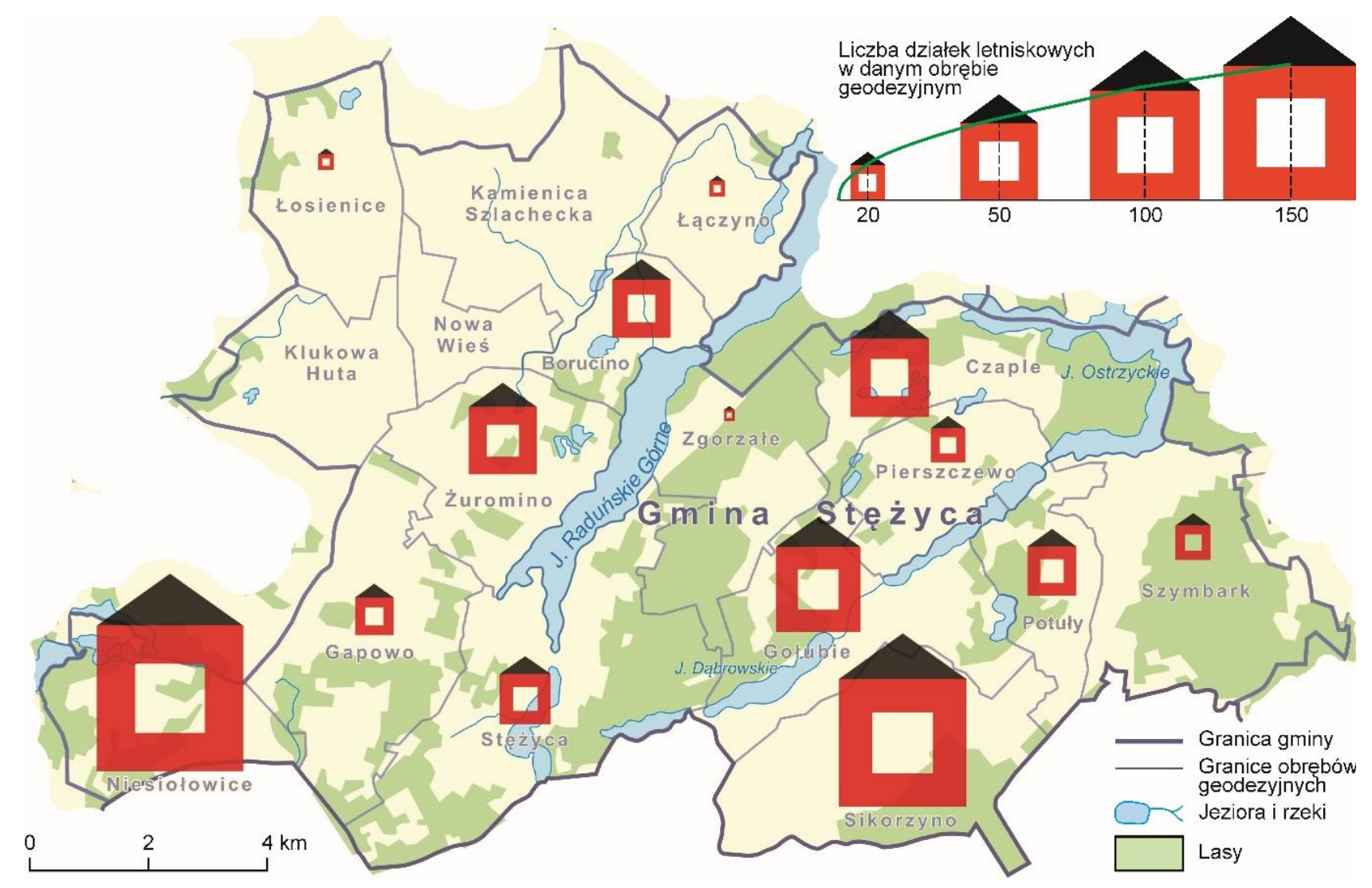

Rysunek 1. Liczba i rozmieszczenie działek letniskowych na terenie gminy Stężyca w $2011 \mathrm{r}$. Źródło: opracowanie własne na podstawie rejestrów wydanych pozwoleń na budowę z wydziałów budowlanych Starostwa Powiatowego w Kartuzach i Urzędu Gminy w Stężycy w latach 1989-2011 
Tabela 2. Podstawowe cechy działek letniskowych w gminie Stężyca

\begin{tabular}{|c|c|c|c|c|c|c|c|c|}
\hline \multirow[b]{2}{*}{ Lp. } & \multirow[b]{2}{*}{$\begin{array}{c}\text { Obręb } \\
\text { geodezyjny }\end{array}$} & \multirow[b]{2}{*}{$\begin{array}{l}\text { Liczba } \\
\text { działek }\end{array}$} & \multicolumn{2}{|c|}{ Średnia powierzchnia } & \multicolumn{4}{|c|}{ Średnia odległość działki od } \\
\hline & & & $\begin{array}{c}\text { domu } \\
\text { letniskowego } \\
\left(\mathrm{m}^{2}\right)\end{array}$ & $\begin{array}{c}\text { działki } \\
\left(\mathrm{m}^{2}\right)\end{array}$ & $\begin{array}{l}\text { jeziora } \\
(\mathrm{m})\end{array}$ & $\begin{array}{c}\text { miejsca } \\
\text { zamieszkania } \\
\text { inwestora } \\
(\mathrm{km})\end{array}$ & $\begin{array}{c}\text { jednostki } \\
\text { wyższego } \\
\text { rzędu } \\
(\mathrm{km})\end{array}$ & $\begin{array}{c}\text { parku } \\
\text { krajobrazowego } \\
\text { lub narodowego } \\
(\mathrm{km})\end{array}$ \\
\hline 1 & Borucino & 28 & 67,22 & 1100,71 & 387,42 & 64,38 & 5,74 & - \\
\hline 2 & Czaple & 51 & 75,24 & 956,71 & 396,69 & 56,79 & 7,13 & - \\
\hline 3 & Gapowo & 12 & 74,91 & 864,92 & 312,08 & 47,77 & 3,14 & 2,50 \\
\hline 4 & Gołubie & 60 & 76,06 & 1184,28 & 309,52 & 65,72 & 5,21 & - \\
\hline 5 & Łączyno & 2 & 84,17 & 1010,00 & 88,51 & 41,35 & 7,68 & - \\
\hline 6 & Eosienice & 2 & 75,36 & 809,00 & 102,56 & 48,02 & 9,27 & 5,30 \\
\hline 7 & Niesiołowice & 176 & 73,64 & 956,21 & 422,95 & 62,80 & 6,55 & 5,50 \\
\hline 8 & Pierszczewo & 10 & 74,28 & 1951,30 & 247,72 & 81,26 & 6,76 & - \\
\hline 9 & Potuły & 20 & 68,38 & 762,95 & 319,56 & 41,29 & 9,10 & - \\
\hline 10 & Sikorzyno & 135 & 69,56 & 1163,22 & 860,57 & 42,20 & 5,45 & 1,50 \\
\hline 11 & Stężyca & 21 & 80,73 & 862,14 & 541,81 & 48,99 & 0,00 & - \\
\hline 12 & Szymbark & 10 & 64,69 & 806,30 & 586,13 & 35,78 & 11,56 & - \\
\hline 13 & Zgorzałe & 1 & 166,00 & 5550,00 & 9,12 & 46,97 & 4,00 & - \\
\hline 14 & Żuromino & 38 & 68,11 & 1024,74 & 321,66 & 47,05 & 2,75 & - \\
\hline \multicolumn{2}{|c|}{ Gmina Stężyca } & 566 & 79,88 & 1357,32 & 350,45 & 52,17 & 6,02 & 1,06 \\
\hline
\end{tabular}

Źródło: opracowanie własne; obliczeń powierzchni dokonano na podstawie map z Geoportalu Infrastruktury Informacji Przestrzennej (2012).

Tabela 3. Podstawowe statystyki opisowe powierzchni działek letniskowych w gminie Stężyca

\begin{tabular}{|c|c|c|}
\hline Lp. & Wyszczególnienie & Wartość \\
\hline 1 & Liczba działek & 566 \\
\hline 2 & Mediana $\mathrm{w} \mathrm{m}^{2}$ & 983,36 \\
\hline 3 & Minimum $\mathrm{w} \mathrm{m}^{2}$ & 281,00 \\
\hline 4 & Maksimum $\mathrm{w} \mathrm{m}^{2}$ & 5550,00 \\
\hline 5 & Kwartyl dolny w $\mathrm{m}^{2}$ & 696,75 \\
\hline 6 & Kwartyl górny $\mathrm{w} \mathrm{m}^{2}$ & 1108,50 \\
\hline 7 & Odchylenie standardowe $\mathrm{w} \mathrm{m} \mathrm{m}^{2}$ & 1242,29 \\
\hline 8 & Kurtoza w m² & 54,52 \\
\hline
\end{tabular}

Źródło: opracowanie własne na podstawie rejestrów wydanych pozwoleń na budowę z wydziałów budowlanych Starostwa Powiatowego w Kartuzach i Urzędu Gminy w Stężycy w latach 1989-2011. Obliczeń powierzchni dokonano na podstawie map z Geoportalu Infrastruktury Informacji Przestrzennej (2012).

W okresie 1989-2011 r. liczba pozwoleń wydanych na budowę domów letniskowych $\mathrm{w}$ gminie Stężyca była w poszczególnych latach mocno zróżnicowana (rys. 2). Najwięcej, bo aż 44 pozwolenia, wydano w 1998 r., następnie 35 w 1992 r. i 34 w 2002 r. Najmniejsza liczba wydanych pozwoleń przypadła na: 1993 r. (11 pozwoleń), 2004 r. (14 pozwoleń) i 1991 r. (15 pozwoleń).

Biorąc pod uwagę liczbę wydanych pozwoleń na budowę domu, można stwierdzić, że najwięcej działek letniskowych odnotowano $\mathrm{w}$ obrębie geodezyjnym Niesiołowice (176), który należy do bardzo atrakcyjnych rejonów Pojezierza Kaszubskiego. Drugim pod względem liczby takich pozwoleń był obręb Sikorzyno, położony w południowej części gminy. Rozwój budownictwa letniskowego nastąpił tu dopiero po 1997 r., przy czym inaczej niż w pozostałych obrębach nagły wzrost zakupu działek przypadł na lata 2010-2011. Najmniej działek letniskowych z zabudową rekreacyjną zewidencjonowano w obrębach geodezyjnych: Zgorzałe oraz Łączyno i Łosienice. Należy podkreślić, że większość z tych działek znajduje się w pobliżu jezior: Dąbrowskiego, Patulskiego i Ostrzyckiego, położonych w centralnej części gminy, w obrębach Gołubie oraz Czaple, ale także w obrębach, które graniczą bezpośrednio ze zbiornikami wodnymi (np. Niesiołowice w części północno-zachodniej).

W celu określenia geograficznych uwarunkowań rozmieszczenia budownictwa letniskowego w prezentowanej gminie przyjęto - za Kowalczykiem $(1986,1994)$ oraz Aldskogiusem (1967) - zestaw zmiennych dotyczących walorów przyrodniczych środowiska oraz zmienne dotyczące dostępności komunikacyjnej (tab. 2). Przedstawiono tylko te zmienne, które zostały zmierzone na mapach WMS, udostępnionych przez Główny Urząd Geodezji i Kartografii.

Analiza uśrednionych pomiarów dotycząca cech działek letniskowych w gminie pozwoliła ustalić, że średnia powierzchnia działki letniskowej wynosi ok. $1357 \mathrm{~m}^{2}$, a domu letniskowego - blisko $80 \mathrm{~m}^{2}$. Przeciętna działka położona jest $\mathrm{w}$ odległości 350,5 m od jeziora, od jednostki wyższego rzędu (tj. miejscowości gminnej) - ok. $6 \mathrm{~km}$, natomiast od najbliższego parku krajobrazowego - blisko $1 \mathrm{~km}$. Właściciele działek letniskowych mieszkają na stałe średnio w odległości $52 \mathrm{~km}$ od swoich działek.

Największe powierzchniowo działki letniskowe zajmują centralną część gminy Stężyca i położone są w obrębie geodezyjnym Pierszczewo (średnia powierzchnia 


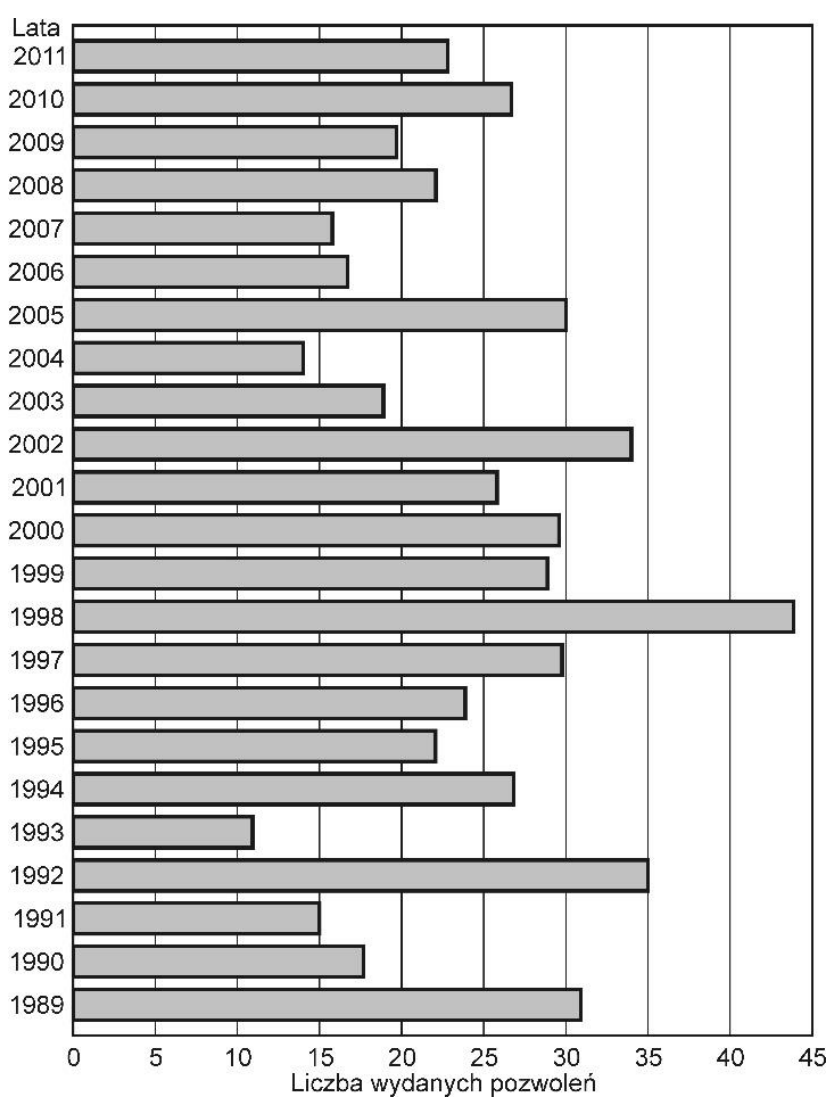

Rysunek 2. Liczba wydanych pozwoleń na budowę domów letniskowych w gminie Stężyca w latach 1989-2011

Źródło: opracowanie własne na podstawie rejestrów pozwoleń wydanych na budowę z wydziałów budowlanych Starostwa Powiatowego w Kartuzach i Urzędu Gminy w Stężycy w latach 1989-2011

- 1951,30 m²) i Gołubie (1184,28 m²). Najmniejsze działki znajdują się natomiast $\mathrm{w}$ obrębie Potuły $\left(762,95 \mathrm{~m}^{2}\right)$. Zróżnicowane są również powierzchnie domów letniskowych w poszczególnych obrębach. Największe występują w obrębach Łączyno $\left(84,17 \mathrm{~m}^{2}\right)$ i Stężyca $\left(80,73 \mathrm{~m}^{2}\right)$. Właściciele domów letniskowych mają najdłuższą drogę do jeziora w obrębach geodezyjnych Sikorzyno (ok. 860,6 m) i Szymbark (około $586 \mathrm{~m}$ ). Najbliżej jezior znajdują się działki w obrębach: Zgorzałe (w odległości ok. 9 m), Łączyno (89 m) i Łosienice (102,6 m).

Należy zaznaczyć, że większość obrębów geodezyjnych położona jest $w$ granicach Kaszubskiego Parku Krajobrazowego. Jedynie działki letniskowe zlokalizowane w obrębach geodezyjnych Gapowo, Łosienice, Niesiołowice i Sikorzyno mają do najbliższego parku maksymalnie ok. $5 \mathrm{~km}$.

Reasumując, największa działka letniskowa w gminie miała powierzchnię $5550 \mathrm{~m}^{2}$ (w obrębie Zgorzałe), a najmniejsza - $281 \mathrm{~m}^{2}$ (w Sikorzynie). Średnia modułów odchyleń wartości dla wszystkich wielkości działek letniskowych w omawianej gminie wyniosła zaś $983,4 \mathrm{~m}^{2}$. Z przeprowadzonych analiz wynika, że gminę cechuje dość duże zróżnicowanie pod względem wielkości działek, na co wskazuje wartość odchylenia standardowego.

\section{CECHY DEMOGRAFICZNE I SPOŁECZNE ORAZ POCHODZENIE TERYTORIALNE WŁAŚCICIELI DZIAŁEK LETNISKOWYCH W GMINIE STĘŻYCA}

Jednym z podstawowych zagadnień, którego dotyczy większość badań marketingowych, pozostaje dokładne określenie segmentów rynkowych. Przy rozwiązaniu tej kwestii wykorzystuje się założenie, że ludzie o podobnych cechach mają podobne zachowania konsumpcyjne (Ruch turystyczny w Łodzi..., 2012). Charakterystyka społeczno-demograficzna została przygotowana, jak wspomniano wcześniej, na podstawie badań ankietowych przeprowadzonych w lipcu i sierpniu $2013 \mathrm{r}$. wśród 104 właścicieli domów letniskowych w obrębach geodezyjnych Niesiołowice i Sikorzyno.

Jak wynika z tych badań, właściciele domów letniskowych w większości (99,1\% ankietowanych) pochodzili z regionalnego rynku turystycznego, czyli z województwa pomorskiego. W segmencie tym aż 84 osoby $(80,8 \%)$ pochodziły z Trójmiasta (z Gdańska - 54,9\% respondentów, z Gdyni - 19,2\%, z Sopotu - 6,7\%) (rys. 3). Pozostali właściciele wywodzili się z obszaru powiatu kartuskiego $(13,5 \%)$ oraz innych powiatów położonych na terenie województwa pomorskiego (słupskiego, tczewskiego i gdańskiego). Spoza regionu odnotowano tylko mieszkańców województwa mazowieckiego.

Biorąc pod uwagę płeć ankietowanych właścicieli działek letniskowych, można uznać, że występowali oni omal w wyrównanych proporcjach - w badaniu wzięło udział 45 kobiet (43,3\%) oraz 59 mężczyzn (56,7\%). Największy odsetek wśród respondentów stanowiły osoby w wieku pomiędzy 26. a 35. rokiem życia $(29,8 \%)$, następnie w wieku 56-65 lat (23,1\%). Najmniej liczną grupą byli badani w wieku 36-45 lat i osoby poniżej 25 . roku życia - łącznie 8,7\% (rys. 4).

Właściciele badanych działek to ludzie aktywni zawodowo, reprezentujący różne zawody i z różnym poziomem wykształcenia. Najwięcej respondentów pracowało w zawodach: rolnika, ogrodnika, leśnika lub rybaka (25\% respondentów), specjalisty $(23,1 \%)$, pracownika usług osobistych lub sprzedawcy $(21,2 \%)$, a najmniej jako zatrudnieni przy pracach prostych oraz w siłach zbrojnych (po 1\%). Jak wynika z przeprowadzonych badań, większość ankietowanych odebrała wykształcenie policealne $(36,9 \%)$, a najmniejszą grupę stanowili respondenci z wykształceniem średnim (6,8\%). Ankietowani z wykształceniem wyższym stanowili $12,6 \%$.

Właściciele drugich domów w badanych obrębach gminy Stężyca z reguły tworzyli gospodarstwa domowe liczące cztery $(38,5 \%)$ lub dwie osoby $(34,6 \%)$. Mniejszą grupę $(15,4 \%)$ stanowili respondenci pochodzący z rodzin składających się z pięciu i więcej osób, a najmniejszy był odsetek $(2,9 \%)$ rodzin trzyosobowych. 


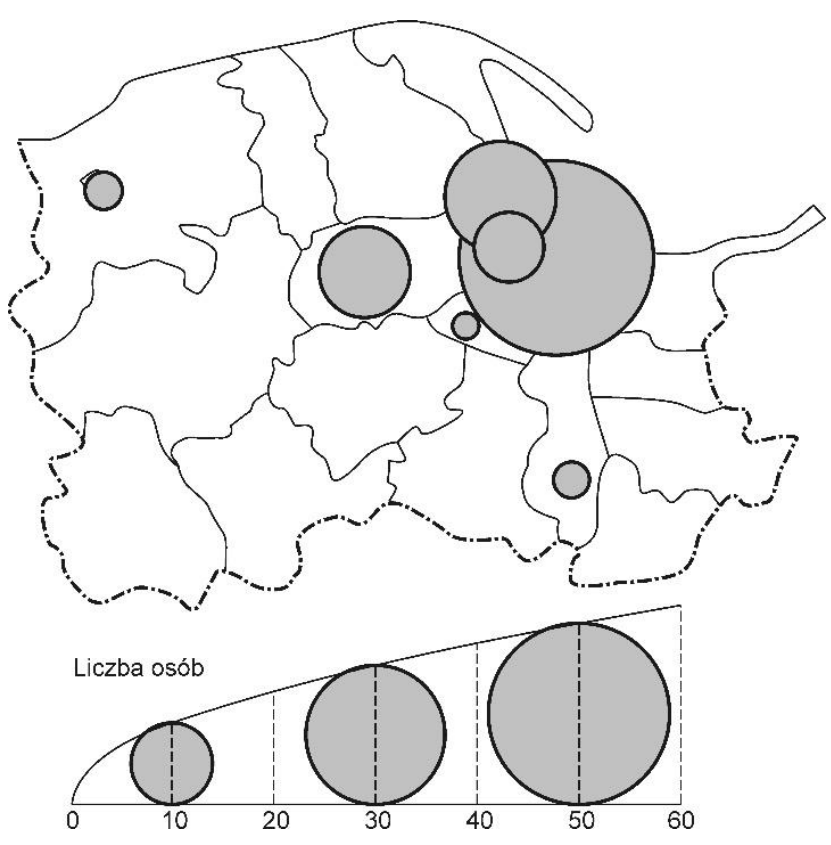

Rysunek 3. Pochodzenie terytorialne właścicieli działek letniskowych w obrębach geodezyjnych Niesiołowice i Sikorzyno

Źródło: opracowanie własne na podstawie badań ankietowych z 2013 r.
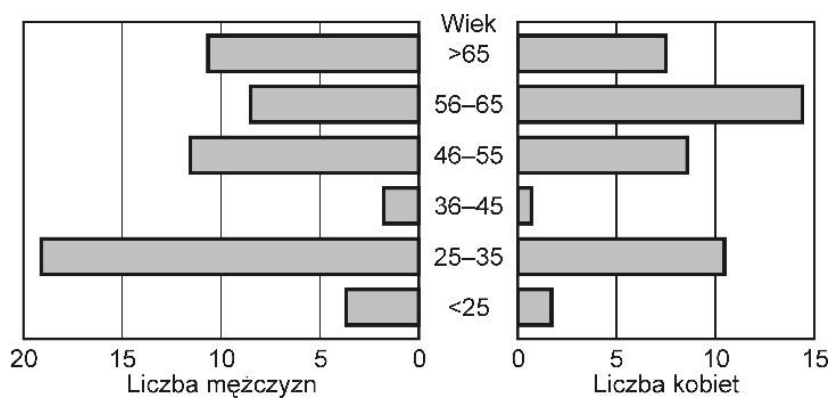

Rysunek 4. Struktura płci i wieku właścicieli domów letniskowych w świetle prowadzonych badań ankietowych na terenie obrębów geodezyjnych Niesiołowice i Sikorzyno Źródło: opracowanie własne na podstawie badań ankietowych z 2013 r.

Ankietowani przyjeżdżali na działki zazwyczaj własnymi samochodami (86,5\%) lub jednośladami (rowerem bądź motorem - 9,6\%).

Większość respondentów zgadzała się, że posiadanie działki letniskowej przynosi wiele korzyści. Do mocnych stron zaliczano: bliskość jezior (78,8\% odpowiedzi) oraz ciszę i spokój (14,4\%). W mniejszym stopniu ankietowani doceniali przyjazne otoczenie i występującą tu bazę turystyczną (odpowiednio 1,9\% i 2,9\%). Spośród słabych stron tej lokalizacji wymieniano przede wszystkim zły stan techniczny dróg $(38,5 \%)$ oraz utrudnioną dostępność komunikacyjną publicznymi środkami transportu $(36,5 \%)$.

\section{ZAGOSPODAROWANIE, MOTYWY NABYCIA I FORMY REKREACJI NA DZIAŁKACH LETNISKOWYCH W GMINIE STĘŻYCA}

Jak wynika z prowadzonych badań terenowych, na terenie gminy Stężyca można wyróżnić kilka architektonicznych typów domów letniskowych, m.in. właściwe drugie domy, domki składane, stałe i ruchome przyczepy mieszkalne. Interesującym przykładem domów letniskowych są na Kaszubach adaptowane do celów wypoczynkowych stare wiejskie chaty. Dzięki temu, przy okazji zagospodarowania rekreacyjnego gminy Stężyca, ratuje się tradycyjną architekturę wiejską.

Znamienną cechą domów letniskowych jest coraz częściej spotykane przystosowanie ich do całorocznego użytkowania. Nowe są budowane $\mathrm{z}$ reguły z cegły lub pustaków, z dachem pokrytym blachą lub dachówką. Często właściciele działek dostawiają budynki gospodarcze i garaże, co wskazuje na chęć wydłużania pobytu, a także przebywania na działkach poza sezonem letnim (rys. 5).

Prowadzone badania ankietowe wśród właścicieli drugich domów pozwoliły także na zaprezentowanie okoliczności nabycia działki letniskowej oraz informacji pozwalających na ustalenie ich zróżnicowania pod względem powierzchni lub zagospodarowania. $\mathrm{Z}$ analizy materiału badawczego wynika, że prawie $3 / 4$ respondentów nabyło działkę w latach 1991-1995 (48,1\%) oraz 2001-2005 (27,9\%). Mniejsze zainteresowanie zakupem działki przypadało na lata 2006-2010 (8,7\%). Najmniejsza liczba badanych osób kupiła teren pod zabudowę letniskową przed 1980 r. Większość właścicieli działek letniskowych w gminie Stężyca dokonała zakupu od osób prywatnych $(63,5 \%)$ lub otrzymała w spadku czy w formie darowizny $(22,1 \%)$. Pozostali kupili działki od gminy (14,4\%) (rys. 6).

Jak wynika z przeprowadzonych badań ankietowych, na terenie gminy Stężyca dominowały działki letniskowe o średniej powierzchni, wynoszącej od 500 do $1000 \mathrm{~m}^{2}$ (68,3\% ogólnej liczby działek). Mniejszym zainteresowaniem cieszyły się działki duże - powyżej $1000 \mathrm{~m}^{2}(20,2 \%)$ i małe - poniżej $500 \mathrm{~m}^{2}(11,5 \%)$. Z kolei powierzchnia drugich domów nie była skorelowana z powierzchnią działki letniskowej. Większość stanowiły domy mające powierzchnię $50-100 \mathrm{~m}^{2}(69,2 \%)$ oraz poniżej $50 \mathrm{~m}^{2}(24,1 \%)$. Stwierdzono niższy udział (3,8\%) domów o powierzchni $100-150 \mathrm{~m}^{2}$ i powyżej $150 \mathrm{~m}^{2}(2,9 \%)$.

Prezentowane badania umożliwiły także dokładną charakterystykę działek ze względu na ich wygląd i zagospodarowanie. Domy letniskowe na terenie gminy wybudowano w większości według indywidualnego projektu $(80,8 \%)$, istniały także inne obiekty zaadaptowane do celów rekreacyjnych $(11,5 \%)$ lub gotowe produkty fabryczne $(7,7 \%)$. 


\section{NIESIOŁOWICE}

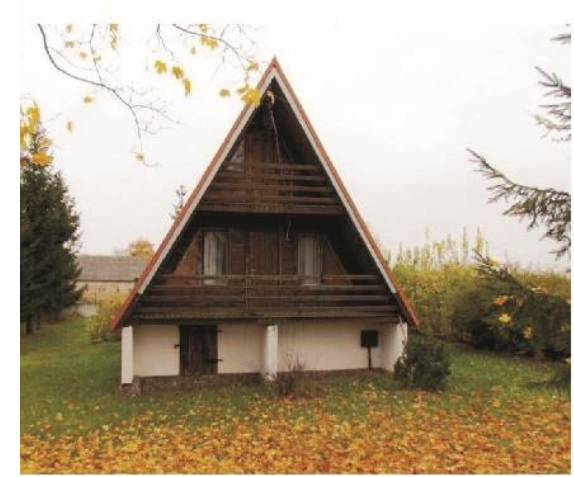

rok budowy: 1985

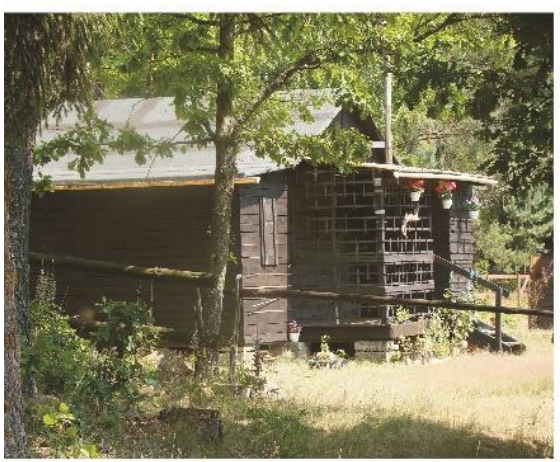

rok budowy: 1988

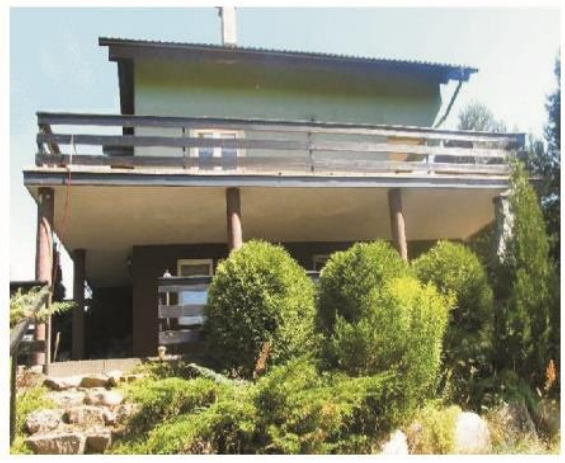

rok budowy: 2006

SIKORZYNO

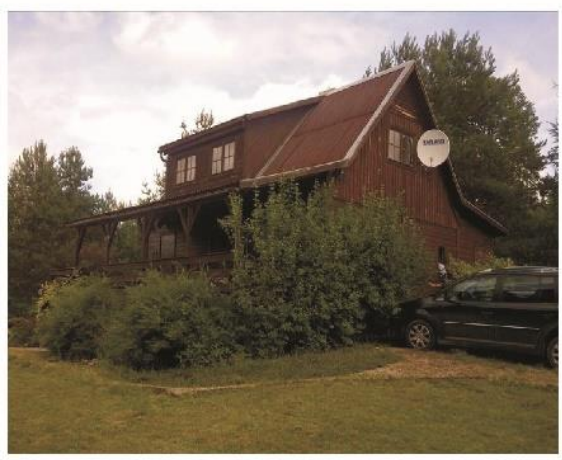

rok budowy: 2001

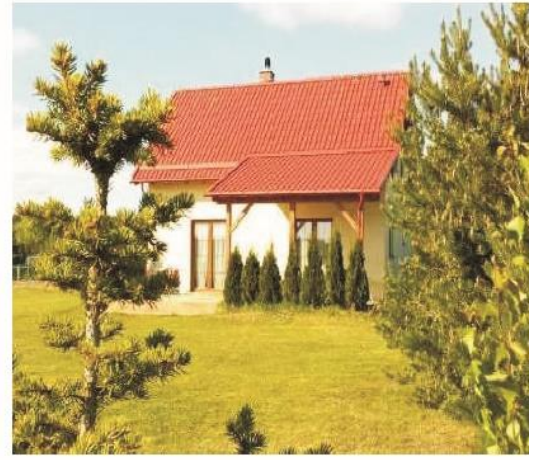

rok budowy: 2010

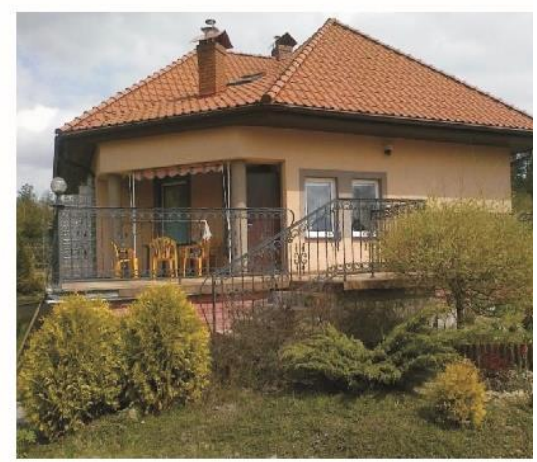

rok budowy: 2007

Rysunek 5. Wybrane typy domów letniskowych na terenie obrębów geodezyjnych Niesiołowice i Sikorzyno Źródło: fot. A. Zienkiewicz

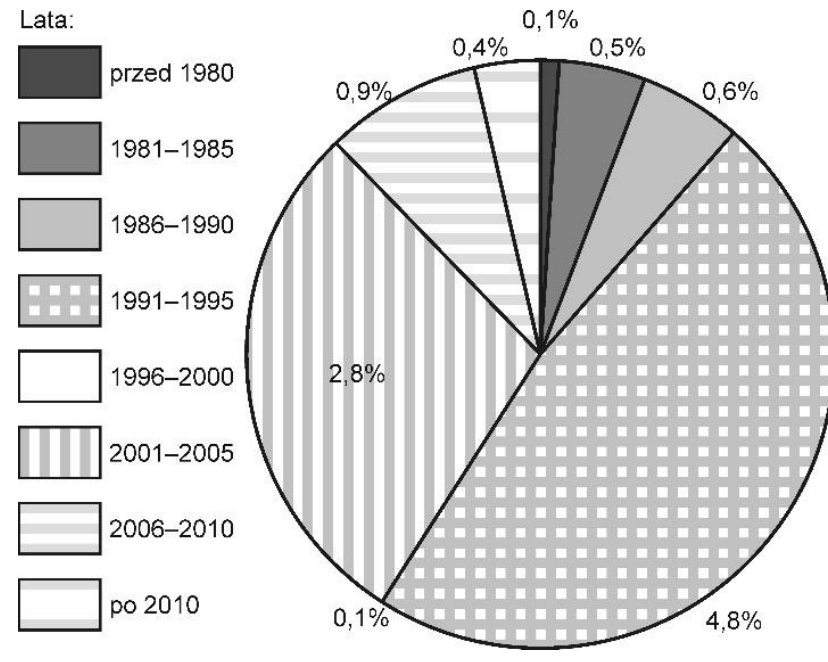

Rysunek 6. Okres budowy domów letniskowych na terenie obrębów geodezyjnych Niesiołowice i Sikorzyno Źródło: opracowanie własne na podstawie badań ankietowych z 2013 r.

W rezultacie prowadzonych badań okazało się, że działki letniskowe są stosunkowo dobrze wyposażone w infrastrukturę techniczną. Wszystkie bowiem miały sieć wodociągową, a 94,2\% było wyposażonych w szamba lub kanalizację. Część budynków miała centralne ogrzewanie do użytku całorocznego (17,3\%). Niewielki odsetek (1,9\%) stanowiły działki z podłączeniem do sieci gazowej.

W świetle niniejszego badania ankietowego przeciętny dom letniskowy jest budynkiem parterowym (31,7\%) lub parterowym z poddaszem (26\%), zbudowanym z pustaków $(41,3 \%)$ lub drewna $(39,4 \%)$. Ma on pokrycie dachu z blachy (36,5\%) lub dachówki (29,8\%).

Ważnym elementem zagospodarowania działek jest umiejscowienie na ich terenie dodatkowego wyposażenia (rys. 7). Zazwyczaj przy domach letniskowych znajdowały się garaże lub wiaty (28,8\% ogółu odpowiedzi). Prawie $1 / 4$ właścicieli posiadała wyznaczone na działce letniskowej miejsca do grillowania i przygotowane wiaty na opał, obiekty rolniczo-produkcyjne, głównie szklarnie, które znalazły się u 11,5\% ankietowanych. Najmniejszy odsetek stanowiły elementy sportowe (5,8\%).

Nie mniej ważne zagadnienie w analizie budownictwa służącego wypoczynkowi indywidualnemu stanowią uwarunkowania związane ze sferą duchową ich właścicieli. Czynniki percepcyjne, psychologiczne oraz motywacyjne kolonizatorów turystycznych mają odzwierciedlenie zarówno w samym fakcie posiadania działki letniskowej, jak i w motywach wyboru konkretnej lokalizacji (Szkup, 2003). 
Wyposażenie dodatkowe Garaże, wiaty samochodowe Inne (np. grill, miejsce do zabaw z dziećmi)

Nasadzenia drzew i krzewów

Rolniczo-produkcyjne (szklarnie, kurniki itp.)

Sportowe (kort, basen itp.)

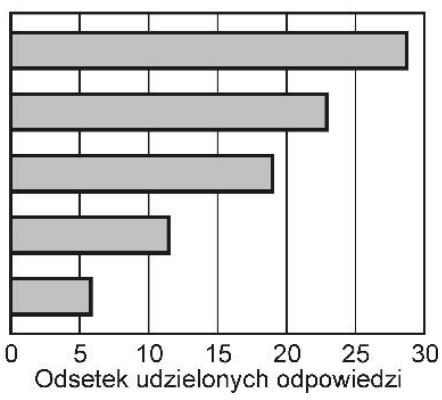

Rysunek 7. Elementy dodatkowego wyposażenia na działkach letniskowych na terenie obrębów geodezyjnych Niesiołowice i Sikorzyno

Źródło: opracowanie własne na podstawie badań ankietowych z $2013 \mathrm{r}$.

Powody nabycia działek letniskowych można odnieść do ogólnych motywów podróży, zaprezentowanych w 1996 r. przez Przecławskiego, i wyróżnić co najmniej dziewięć uzasadnień lokalizacji działek letniskowych. Są to m.in.: pragnienie udania się do określonej miejscowości letniskowej, poznanie określonego typu przyrody lub życia społecznego mieszkańców, opuszczenie na jakiś czas miejsca stałego pobytu, chęć spędzania czasu z rodziną, znajomymi lub partnerem życiowym. Osoby posiadające działkę letniskową przy wyborze swej aktywności mogą również kierować się pragnieniem zawarcia nowych znajomości. Uważa się też, że dość częstym motywem, do którego niechętnie przyznają się właściciele działek, jest zwyczajny snobizm, który płynie z chęci utrzymania lub podwyższenia swojego prestiżu społecznego. Do pozostałych motywów należą także takie, które wiążą się z zaspokajaniem potrzeb emocjonalnych, estetycznych i twórczych (Przecławski, 1996). Na działce letniskowej, w niedalekiej odległości od jeziora lub lasu, można bowiem nawiązać bliski kontakt z przyrodą, co wpływa korzystnie na rozwój artystyczny czy naukowy osób przebywających poza miejscem stałego zamieszkania. Ważnym motywem nabywania działek, szczególnie na Kaszubach, jest pragnienie odwiedzania terenów, na których się kiedyś mieszkało.

Motywy nabycia działki letniskowej w poszczególnych obrębach geodezyjnych okazały się zróżnicowane (rys. 8). Najwięcej osób wskazywało na walory przyrodnicze $(29,2 \%$ w obrębie Sikorzyno, 30,4\% w obrębie Niesiołowice) oraz bliskość miejsca zamieszkania $(18,8 \%$ w obrębie Sikorzyno, 42,9\% w obrębie Niesiołowice). Pozostałe powody nabycia działki letniskowej na badanym terenie to: w obrębie Sikorzyno namowa znajomych oraz dogodne połączenie komunikacyjne (po 18,8\%), natomiast w obrębie Niesiołowice - przypadek lub okazja $(12,5 \%)$ oraz chęć ulokowania środków finansowych $(5,4 \%)$. Uogólnione wyniki badań dowodzą, że decydującym motywem nabycia działki okazała się bliskość stałego miejsca zamieszkania ich inwestorów $(31,7 \%$ badanych), następnie walory przyrodnicze $(29,8 \%)$ oraz

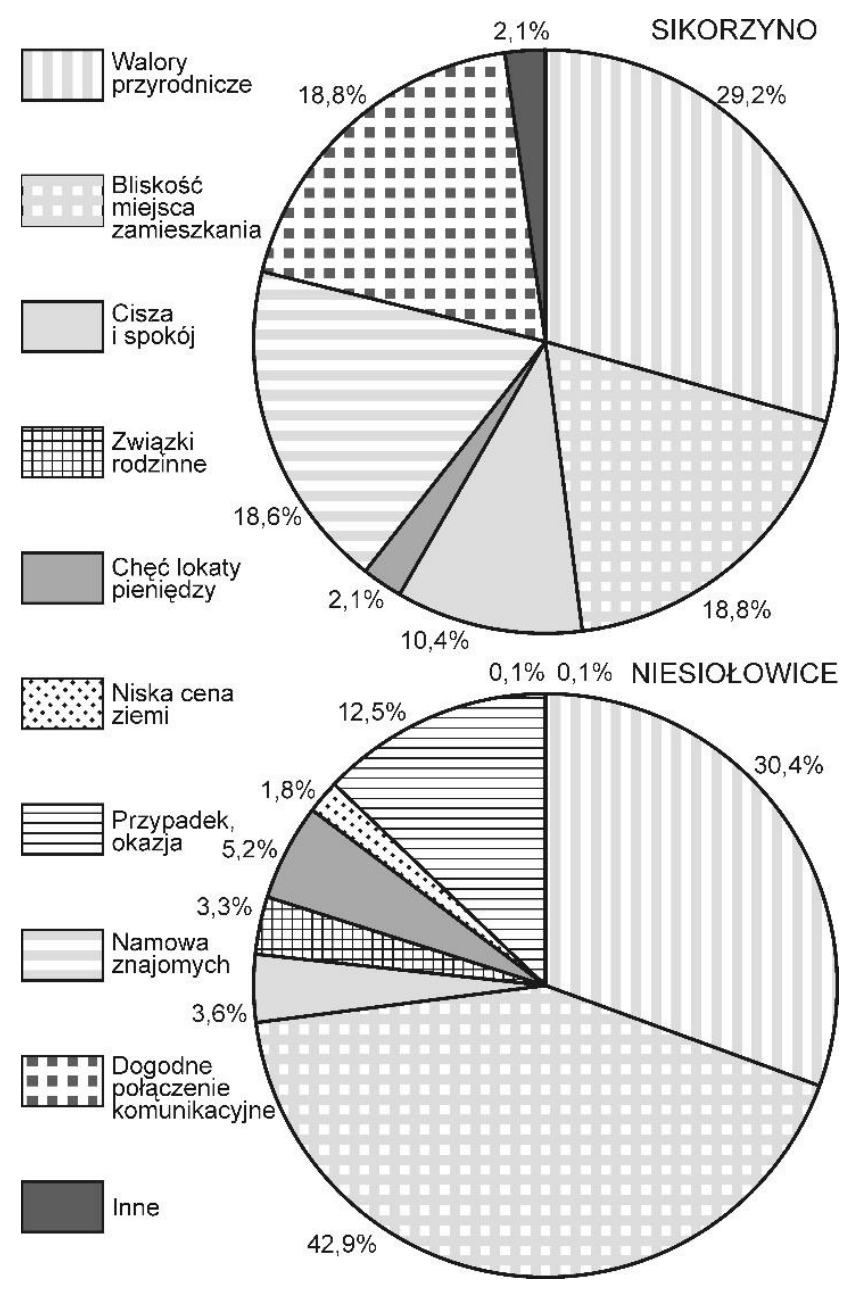

Rysunek 8. Motywy nabycia działki letniskowej w obrębach geodezyjnych Sikorzyno i Niesiołowice

Źródło: opracowanie własne na podstawie badań ankietowych z 2013 r.

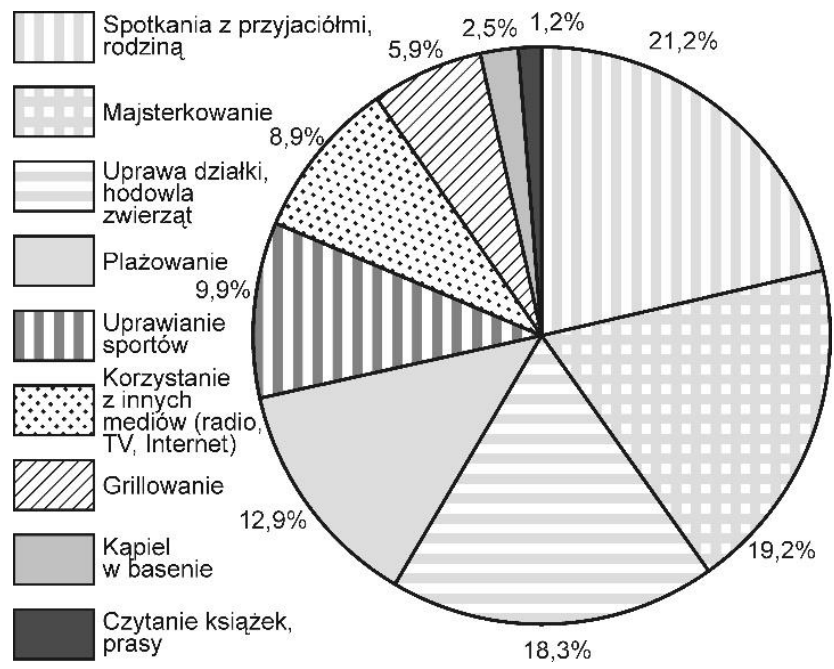

Rysunek 9. Formy spędzania wolnego czasu na działkach letniskowych

na przykładzie obrębów geodezyjnych Sikorzyno i Niesiołowice Źródło: opracowanie własne na podstawie badań ankietowych z 2013 r. 
namowa znajomych i dogodne połączenie komunikacyjne (po 8,7\%).

Formy spędzania wolnego czasu na działkach letniskowych przez właścicieli i ich rodziny były także zróżnicowane (rys. 9). Respondenci najchętniej wymieniali spotkania z przyjaciółmi i rodziną $(21,2 \%)$, majsterkowanie $(19,2 \%)$ i zajmowanie się symboliczną uprawą owoców i warzyw, ale także chowem zwierząt (głównie drobiu i królików) czy opieką nad swoimi zwierzętami domowymi (18,3\%). Pozostałymi formami spędzania czasu były: plażowanie, uprawianie sportów, korzystanie z radia, telewizji i Internetu, grillowanie, kąpiel w przydomowym basenie oraz czytanie prasy i książek.

\section{UWAGI KOŃCOWE}

Z przeprowadzonych badań wynika, że gmina Stężyca, położona na terenie Szwajcarii Kaszubskiej, jest atrakcyjnym miejscem do lokalizacji drugich domów. Jednoznacznie można stwierdzić, że o rozwoju osadnictwa letniskowego na tym terenie decydują zasoby i walory przyrodnicze. Są to przede wszystkim liczne systemy jezior o genezie polodowcowej, wykorzystywane jako bardzo atrakcyjne szlaki wodne na rzece Raduni. Dodatkowo rozwojowi funkcji wypoczynkowej sprzyjają: położenie na terenie Kaszubskiego Parku Krajobrazowego, rozległe obszary leśne $\mathrm{z}$ dominacją lasów mieszanych i borów mieszanych świeżych, które zajmują prawie $1 / 3$ powierzchni gminy. Należy również podkreślić, że zainteresowanie kupnem działki letniskowej budzą: położenie w strefie bezpośredniego oddziaływania Trójmiasta i rosnąca potrzeba regeneracji sił witalnych przez mieszkańców aglomeracji gdańskiej przy wzroście dni wolnych od pracy.

Najwięcej działek letniskowych kupiono na początku lat 90. XX w., co - jak należy sądzić - było pozytywnym efektem rozwoju funkcji turystycznej w okresie transformacji systemowej. Głównym zaś motywem nabycia działki była bliskość stałego miejsca zamieszkania i wysoka atrakcyjność przyrodnicza gminy. Koncentracja działek występuje w części zachodniej oraz południowej gminy, co wyraźnie nawiązuje do rozmieszczenia największych jezior na badanym obszarze. $Z$ reguły były to działki zabudowane domami letniskowymi o różnych typach architektonicznych, łącznie ze starymi wiejskimi chatami zaadaptowanymi do celów wypoczynkowych. Prowadzone badania ankietowe na terenie obrębów geodezyjnych Niesiołowice i Sikorzyno wykazały, że typowy dom letniskowy to obiekt wybudowany według indywidualnego projektu, parterowy lub parterowy z poddaszem, zbudowany z pustaków bądź drewna i pokryty blachą albo dachówką. Działki letniskowe respondentów odznaczały się również specyficznym sposobem zagospodarowania. Największy odsetek urządzeń na działkach stanowiły garaże i wiaty samochodowe, jak również miejsca do zabaw z dziećmi i na grill.

Właścicielami działek były osoby o zróżnicowanej strukturze społeczno-demograficznej, jednak dominowali respondenci w wieku 26-35 i 56-65 lat. Jak wynika z badań, większość kolonizatorów mieszkała w Trójmieście, ale tak naprawdę nigdy nie zerwała związków $z$ miejscem swego urodzenia. Jest to dobry przykład istnienia więzi i poczucia tożsamości z regionem kulturowym, jakim pozostają Kaszuby.

\section{PRZYPIS}

1 Wielkość próby do badania ankietowego obliczono dla populacji 311. N poziomie ufności 0,95 , przy szacowanej wielkości frakcji 0,5, błędzie maksymalnym 3\%, wielkość próby wynosi 241. Ze względu na czynniki niezależne od autorek badania przeprowadzono dla próby 104 osób. Na poziomie ufności 0,95, przy szacowanej wielkości frakcji 0,5 , błąd maksymalny wynosi $8 \%$.

\section{BIBLIOGRAFIA}

Adamiak, C. (2012). Miejsce drugich domów w zagospodarowaniu obszarów wiejskich województwa kujawsko-pomorskiego. Studia Obszarów Wiejskich, 29, 175-191.

Adamiak, C., Sokołowski, D. (2012). Popytowe uwarunkowania indywidualnego osadnictwa turystycznego w Polsce. Zeszyty Naukowe Uniwersytetu Szczecińskiego. Ekonomiczne Problemy Ustug, $83,27-43$.

Aldskogius, H. (1967). Vacation house settlement in the Siljan Region. Geografiska Annaler. Series B: Human Geography, 49 (2), 69-95.

Augustowski, B. (red.) (1979). Pojezierze Kaszubskie. Gdańsk: Gdańskie Towarzystwo Naukowe, Wydawnictwo Ossolineum.

Beaujeu-Garnier, J., Chabot, G. (1971). Zarys geografii miast. Warszawa: Państwowe Wydawnictwo Ekonomiczne.

Durydiwka, M. (2012). Czynniki rozwoju i zróżnicowanie funkcji turystycznej na obszarach wiejskich w Polsce. Warszawa: Wydzia Geografii i Studiów Regionalnych, Uniwersytet Warszawski.

Dziegieć, E. (1989). Przemiany wsi położonych w strefie krajobrazowej pojezierzy. W: Turystyka jako czynnik rozwoju społeczno-gospodarczego. Wyniki prac z lat 1986-1987 (s. 118-141). Warszawa: Instytut Turystyki.

Dziegieć, E., Liszewski S. (1984). Zones suburbaines en tant que terrains de recreation pour les habitants des grondes villes polonaises. Problemy Turystyki, 2, 11-21

Faracik, R. (2006). Turystyka w strefie podmiejskiej Krakowa. Kraków: Instytut Geografii i Gospodarki Przestrzennej, Uniwersytet Jagielloński.

Faracik, R. (2011). Turystyka w strefie podmiejskiej Krakowskiego Obszaru Metropolitalnego. W: M. Durydiwka, K. Duda-Gromada (red.), Przestrzeń turystyczna. Czynniki, różnorodność, zmiany (s. 149-156). Warszawa: Wydział Geografii i Studiów Regionalnych, Uniwersytet Warszawski.

Gacki, T., Szukalski J. (1979). Zróżnicowanie geoekologiczne i regionalne oraz problemy antropizacji $i$ ochrony środowiska geograficznego. W: B. Augustowski (red.), Pojezierze Kaszubskie (s. 221-253), Gdańskie Towarzystwo Naukowe, Wydawnictwo Ossolineum. 
Grucza, J., Grucza K. (2007). Kolonizacja turystyczna Pojezierza Kaszubskiego na przykładzie gmin Sierakowice i Sulęczyno. Stupskie Prace Geograficzne, 3, 203-215.

Heffner, K. (2015). Drugie domy i ich znaczenie dla rozwoju funkcji turystycznej i rekreacyjnej na obszarach wiejskich. Studia KPZK PAN, 166, 45-70.

Heffner, K., Czarnecki, A. (2011). Drugie domy w rozwoju obszarów wiejskich. Warszawa: Instytut Rozwoju Wsi i Rolnictwa Polskiej Akademii Nauk.

Jakóbczyk-Gryszkiewicz, J. (1995). Wybrane aspekty rozwoju funkcji wypoczynkowej w strefach podmiejskich trzech największych miast Polski: Warszawy, Łodzi i Krakowa, Turyzm, 5 (1), 67-77.

Jażewicz, I., Zienkiewicz, A. (2013). Przyrodnicze i antropogeniczne determinanty rozwoju turystyki na Kaszubach W: R. Jaroszewska-Brudnicka, D. Sokołowski (red.), Wspótczesne problemy rozwoju turystyki w ujęciu regionalnym i lokalnym (s. 195-211). Torun: Uniwersytet Mikołaja Kopernika.

Jażewicz, I., Zienkiewicz, A. (2017). Uwarunkowania rozwoju osadnictwa letniskowego w powiecie kartuskim. Prace i Studia Geograficzne Uniwersytetu Warszawskiego, 6 (3), 89-108.

Kowalczyk, A. (1986). Geograficzne uwarunkowania rozmieszczenia budownictwa letniskowego w Polsce. W: D. Szafrańska, M. Tarajkowska, J. Wieczorkowska (red.), II Zjazd Geografów Polskich (s. 201-203). Łódź: Wydawnictwo Uniwersytetu Łódzkiego.

Kowalczyk, A. (1990). Geograficzne uwarunkowania lokalizacji drugich domów w strefie podmiejskiej Warszawy. W: Problemy ochrony $i$ kształtowania środowiska przyrodniczego na obszarach zurbanizowanych. Część II (s. 116-121). Warszawa: Wydawnictwo SGGW-AR.

Kowalczyk, A. (1993). Percepcja jakości wypoczynku w drugim domu (na przykładzie strefy podmiejskiej Warszawy). Turyzm, 3 (2), 33-49.

Kowalczyk, A. (1994). Geograficzno-społeczne problemy zjawiska „drugich domów". Warszawa: Wydział Geografii i Studiów Regionalnych, Uniwersytet Warszawski.

Krukowska, R., Świeca, A. (2008). Osadnictwo letniskowe - jedna z form wykorzystania turystycznego obszarów wypoczynkowych na przykładzie Pojezierza Łęczyńsko-Włodawskiego. W: J. Wyrzykowski (red.), Uwarunkowania rozwoju turystyki zagranicznej w Europie Środkowej i Wschodniej. Tom 10: Turystyka w środowisku geograficznym (s. 187-196). Wrocław: Instytut Geografii i Rozwoju Regionalnego, Uniwersytet Wrocławski.

Krzymowska-Kostrowicka, A. (1995). Zarys geoekologii rekreacji. Człowiek w środowisku przyrodniczym: geoekologia zachowań turystyczno-rekreacyjnych. Tom II. Warszawa: Uniwersytet Warszawski.

Liszewski, S. (1985). Użytkowanie ziemi jako kryterium strefy podmiejskiej. Acta Universitatis Lodziensis. Folia Geographica, 5 75-90.

Liszewski, S. (1987). Geneza i rozwój osadnictwa wypoczynkowego w otoczeniu Łodzi. Acta Universitatis Lodziensis. Turyzm, 3, 33-54.

Liszewski, S. (1991). Spała. Monografia i funkcja miejscowości wypoczynkowej. Turyzm, 1 (2), 5-32.

Makowska-Iskierka, M. (2004). Changes in the morphology of a recreational garden settlement: The case study of Sokolniki. Turyzm/Tourism, 14 (1), 5-19.
Makowska-Iskierka, M. (2011). Procesy urbanizacyjne na terenach turystyczno-wypoczynkowych strefy podmiejskiej Łodzi. Łódź: Łódzkie Towarzystwo Naukowe.

Matczak, A. (1984). Próba wykorzystania analizy morfologicznej do określenia funkcji wypoczynkowej osiedli w strefie podmiejskiej Łodzi. Problemy Turystyki, 2, 93-97.

Matczak, A. (1985). Funkcja wypoczynkowa strefy podmiejskiej Łodzi. Acta Universitatis Lodziensis. Folia Geographica, 5, 299-312.

Matczak, A. (1986). Budownictwo letniskowe w strefie podmiejskiej Łodzi. Acta Universitatis Lodziensis. Folia Geographica, 7, 137-166.

Matczak, A. (1987a). Ruch wypoczynkowy w strefie podmiejskiej Łodzi. Acta Universitatis Lodziensis. Folia Geographica, 8, 21-39.

Matczak, A. (1987b). Próba określenia funkcji wypoczynkowej osiedli podmiejskich na przykładzie Kolumny. Acta Universitatis Lodziensis. Turyzm, 3, 55-85.

Matczak, A. (1991). Funkcja wypoczynkowa osiedli podłódzkich $\mathrm{w}$ świetle badań użytkowania ziemi. Acta Universitatis Lodziensis. Folia Geographica, 13, 129-140.

Matczak, A. (1995). Preferencje kierunkowe w lokalizacji drugich domów w łódzkiej aglomeracji miejskiej. Acta Universitatis Lodziensis. Folia Geographica, 20, 231-237.

Matulewski, P., Tomczak, P. (2013). Czynniki lokalizacji „drugich domów" na przykładzie powiatu brodnickiego. Rozwój Regionalny i Polityka Regionalna, 24, 67-82.

Mordawski, J. (2008). Geografia Kaszub. Gdańsk: Zrzeszenie Kaszubsko-Pomorskie.

Przecławski, K. (1996). Człowiek a turystyka. Zarys socjologii turystyki. Kraków: Wydawnictwo F.H.U. Albis.

Sobolewski, W., Borowiak, D., Borowiak, M., Skowron, R. (2014). Baza danych jezior Polski i jej wykorzystanie w badaniach limnologicznych. Lublin: Uniwersytet Marii Curie-Skłodowskiej, Wydział Nauk o Ziemi i Gospodarki Przestrzennej.

Szkup, R. (2003). Ksztattowanie podmiejskiej przestrzeni wypoczynkowej - przykład zachodniego sektora strefy podmiejskiej Łodzi. Łódź: Wydawnictwo Uniwersytetu Łódzkiego.

Szukalski, J. (1965). Jeziora górnej Raduni. Zeszyty Geograficzne WSP w Gdańsku, VII, 93-128.

Wiluś, R. (1997). Rozwój funkcji turystycznej w dolinie rzeki Warty na odcinku od Działoszyna do Uniejowa. Łódź: Łódzkie Towarzystwo Naukowe.

Włodarczyk, B. (1999). Przemiany form aktywności turystycznej - przykład Krawędzi Wyżyny Łódzkiej. Łódź: Łódzkie Towarzystwo Naukowe.

Wojciechowska, J. (1998). Kolonizacja turystyczna terenów nadpilicznych. Szlakami Nauki, 26, 1-158.

Wyrzykowski, J. (1986). Geograficzne uwarunkowania rozwoju urlopowej turystyki wypoczynkowej w Polsce. Wrocław: Wydawnictwo Uniwersytetu Wrocławskiego.

Zienkiewicz, A. (2016). The role of natural environment in the development of tourism in the Kashubian Lake District (on the example of Kartuzy County). Geosport for Society, 4 (1), 37-50.

Zyber, G. (1977). Szczególne cechy lasu w procesie regeneracji sił psychicznych i fizycznych turysty. Koszalińskie Studia i Materiaty, 3, 59-75.

Artykuł wpłynął 4 czerwca $2019 \mathrm{r}$ Zaakceptowano do druku: 8 sierpnia $2019 \mathrm{r}$. 